\title{
Rational Method Irrationality with Rectification
}

\author{
Zekâi ŞEN $^{1}$
}

\begin{abstract}
Rational method (RM) is the simplest approach for peak discharge calculation, but it has many simplifying and unrealistic assumptions, which cause biased results in many applications. Among the most important drawbacks are its applicability restriction to small areas, but it is also used without much care even for large, flat and horizontal areas, even though drainage basins might have significant slopes and rough topography. In the RM the rainfall intensity is taken as constant during the storm rainfall duration and over the drainage area coverage. In this paper, first the RM irrationalities are explained and then a modified formulation is proposed by reconsidering geomorphologic and rainfall features. Nonlinear relationships, in the forms of double-logarithmic functions, of peak discharge with drainage area and slope are incorporated in the new formulation. Its application is achieved for a set of drainage sub-basins from the Kingdom of Saudi Arabia.
\end{abstract}

Keywords: Drainage area, peak discharge, rainfall intensity, rational method, slopes.

\section{Introduction}

Rainfall-runoff relationship plays a key role in any water resources planning, design, operation, and maintenance study. Flood estimations on small drainage basins are required for a number of engineering structures such as dams, levees, culverts and soil conservation purposes. If in a basin designs are of low cost hydraulic structures then the flood estimation models with large amounts of input data are not warranted. Preferably, parsimonious models are considered with simple basic principles for easy use (Linsley, 1982).

Peak discharge calculations are necessary for flood control studies in water engineering domain. Especially, climate change effects trigger floods in different parts of the world in an unprecedented manner, and hence, more refined formulations are necessary for better estimations through simple models that can be used practically by engineers. The most frequently used methods in flood estimations on small catchments are the rational method (RM) and the Soil Conservation Service (SCS) method (SCS, 1971, 1986). Details of these methods can be obtained readily from the relevant literature (Chow et al., 1988; Linsley, 1982). The main parameter for the RM is the runoff coefficient $(\mathrm{C})$ and for the SCS method the curve number $(\mathrm{CN})$. These methods are used for design flood discharge estimation provided that the design rainfall information is given (Şen, 2008).

Pilgrim and Cordery (1993) present the application of the RM as a design procedure. In many applications $\mathrm{C}$ value is considered as constant, but in nature, it changes with time and especially in

${ }^{1}$ Su Vakfi, Libadiye Caddesi, Doğanay Sokak No: 6, Kat 4, Üsküdar, Istanbul, Turkey

bilgi@suvakfi.org.tr 
the calculation of design discharge average recurrence interval, it plays the single most roles. The variation of $\mathrm{C}$ with time must be considered in any formulation for finding refined rainfall-runoff conversion mechanism (Kadioğlu and Şen, 2001). Estimation of the $C$ value is difficult and it is the major source of uncertainty in many water resources projects. The coefficient must account for all the significant factors affecting the peak flow response to average excess rainfall intensity without areal extent and response time restrictions. In any water resources design, the C's are taken from tables based on a set of drainage features (Maidment, 1993). They are chosen in a rather vague manner and largely include subjective judgments rather than actual field data. Additionally, various studies show that C's vary widely from storm to storm particularly depending on different antecedent wetness and environmental conditions (Hjelmfelt, 1991; Ponce and Hawkins, 1996; Kadioglu and Şen, 2001). Generally, the $C$ increases as the average recurrence interval of rainfall increases, thus allowing for non-linearity in runoff response of the drainage basin. Since considerable judgment and experience are required in selecting satisfactory C's for a design, there is a need to check values against observed runoff data.

It is the main purpose of this paper to modify the rational method assumptions so as to obtain a more flexible and useful methodology for peak discharge estimation. In the new method, drainage area is considered as nonlinearly effective on the peak discharge and also the drainage basin slope is taken into consideration in addition to non-linearity in the rainfall intensity. The application of the proposed methodology is given for Wadi Baish in the Kingdom of Saudi Arabia with its 54 sub-basin considerations.

\section{Criticisms}

$\mathrm{RM}$ is rational on logical bases with simplifying basic assumptions, but it does not seem physically plausible for actual flow cases. Among its assumptions peak flow rate is produced by a constant storm rainfall intensity, which is maintained for a time equal to the period of concentration over the whole drainage basin area. This time is defined theoretically as the time required for the surface runoff from the most remote part of the drainage basin to reach the point of interest. Practically, one cannot measure it in the field, and therefore, it is calculated in an empirical manner (Kirpich, 1944; S Sen, 2010). Additionally, there is a set of assumptions that the engineer should be aware of for successful applications and interpretations of the results. Otherwise, the peak discharge estimation by the classical RM may lead to unreliable conclusions. Among such assumptions are the following points for close consideration.

1) Average excess rainfall intensity has the same recurrence interval with the peak discharge,

2) The excess rainfall is uniformly distributed over the drainage area,

3) The excess rainfall intensity is constant during the time of concentration,

4) Peak discharge volume, uniformly distributed over the drainage area, is directly and linearly dependent on the excess rainfall intensity over the same drainage area. The ratio between the two is referred to as the runoff coefficient,

5) The excess rainfall intensity time is identical to time required for the runoff to flow from the hydraulically most distant point in the contributing drainage area to the point of design, 
6) It is not possible to satisfy all the assumptions simultaneously in any study and there is a less chance that the rainfall rate used in the design might occur actually. Hence, the safety factor cannot be considered in the design,

7) In general, a difference exists between intense point rainfall areal coverage over some portion or the whole drainage area. In such cases, the classical RM yields excessive peak discharge values, and hence, it is necessary to have an area reduction factor (Omolayo, 1993; Surdaş and Şen, 2007), which cannot be determined easily in the practical applications,

8) In an irregularly-shaped drainage basin, a part of the area that has a short time of concentration may cause greater peak discharge at the outlet point than the runoff rate calculated for the entire drainage basin. This is because parts of the area with long concentration times are far less susceptible to high-intensity rainfall,

9) A portion of a drainage area with high permeability produces greater amount of runoff than that calculated for the entire area. In order to reduce the effects of the last three points in the calculations, it is better to subdivide the whole drainage area into a set of convenient sub-areas.

Average knowledge is possible only when a phenomenon or process is isolated from surrounding effects through a set of restrictive assumptions that render the problem into the world of certainty by ignoring all uncertain and fuzzy features. For instance, $\mathrm{C}$ is a multiplier applied to deterministically (Classical two-valued logic) calculated peak discharge according to RM formulation in hydrology. Thus, by effectively "over-engineering" or "under-engineering" the design by strengthening components or including redundant systems, $\mathrm{C}$ accounts for imperfections in hydrologic calculations, flaws in assembly, geomorphologic and geologic degradation, and uncertainty in discharge estimates. In fact, $\mathrm{C}$ includes "ignorance component" due to the exclusion of all uncertain information about the hydrologic design. However, fuzzy logic and system help to solve the hydrologic design problem without considering C explicitly (Şen, 2010).

\section{Method}

Rectification of RM formulation is possible by considering the following logical statements and relationships.

\section{Peak discharge-drainage area relationship}

Is it acceptable that peak discharge, Qp, is directly and linearly proportional with the catchment area, A? If this statement is accepted without criticism then the more the area the more the peak discharge is without any limitation. The first part of this statement has logical validity, but the second part "linearity" is not valid in practical applications. This leads to the logical and rational conclusion that such a relation is non-linear, which brings into mind two non-linear alternatives, I and II as in Figure 2.1. 


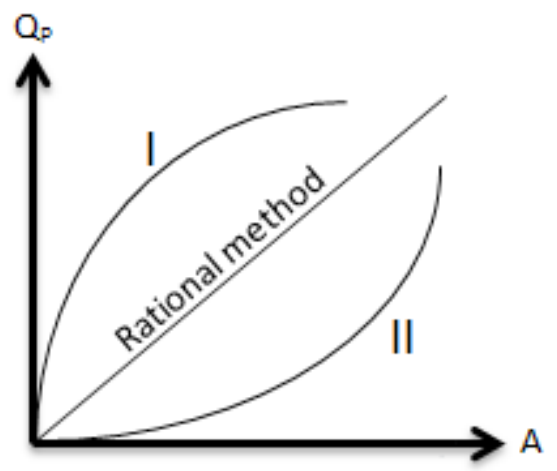

Figure 2.1. Peak discharge drainage area relationship

Rational thinking and many empirical studies indicate that as A increases, excess rainfall initially leads to discharge increment more that linear case (RM) and at large A values the rate of increase starts to decrease. In other words, the slope of peak discharge with respect to area, $\mathrm{dQp} / \mathrm{dA}$, is not a constant value but initially more than this constant (linear RM line) and as the area increases the increment in the discharge value decreases. Hence, type-II nonlinearity case is out of order and type-I is plausible. As a result, it is possible to express such a directly proportional expression mathematically as,

$$
\mathrm{Q}_{\mathrm{p}} \alpha_{\mathrm{A}} \mathrm{A}^{\mathrm{n}}
$$

where $\alpha \mathrm{A}$ is the proportionality sign and $\mathrm{n}$ is a power less than 1 , which can be determined empirically from available data set including different catchment areas and their peak discharges.

The relationship between the catchment area and the peak discharge is related to the area directly as in the RM, but the surface roughness (hills and depressions) give rise to a non-linear relationship between these two quantities.

The plot of worldwide data between the peak discharge and drainage basin by Costa (1987) is presented in Figure 2.2 on double logarithmic

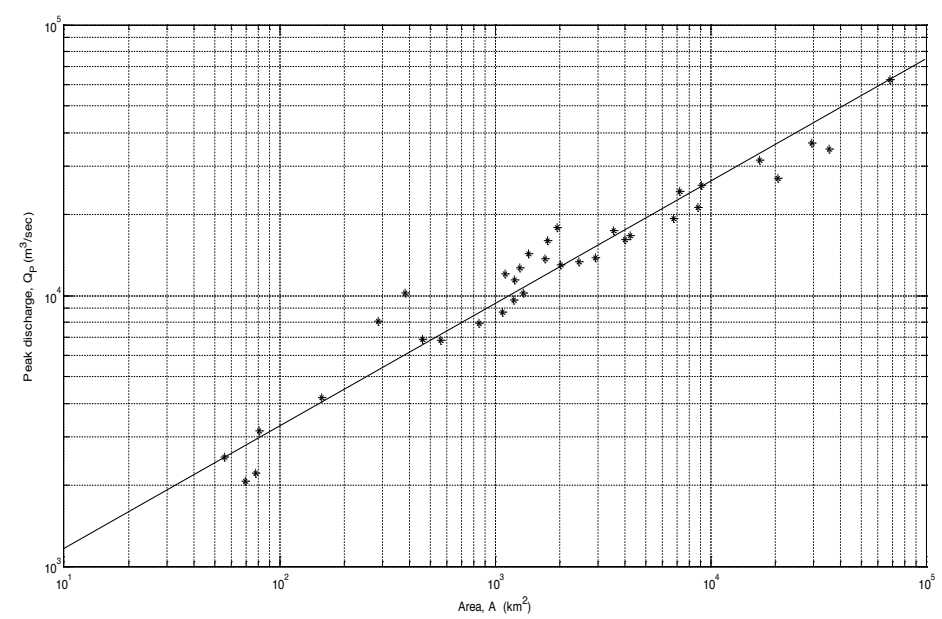

Figure 2.2. Drainage area versus peak discharge 
In this figure the straight line on double logarithmic paper yields to a mathematical function as,

$$
\mathrm{Q}_{\mathrm{P}}=500 \mathrm{~A}^{0.4}
$$

'I his shows a relationship similar to type I curve in Figure 2.1, which implies that the drainage have more hill effective roughness than depression dominance. On the other hand, such a relationship implies rather prompt response of the drainage basin to rainfall intensity to form the surface runoff.

For instance, Bayazıt and Önöz (2008) in their work to find a relationship between Turkish drainage areas and the peak discharge have led to the following conditional expressions.

$$
\begin{array}{lc}
\mathrm{QP}=1.81 \mathrm{~A} 1.22 & \mathrm{~A} \leq 300 \\
\mathrm{QP}=79 \mathrm{~A} 0.5 & 300 \leq \mathrm{A} \leq 10000
\end{array}
$$

In Eq. (1) $n=1$ corresponds to flat areas; $n \neq 1$ represents rough topography within the drainage basin. If $\mathrm{n}>1$, then in the drainage basin hilly areas are more dominant over depressions otherwise when $\mathrm{n}<1$ the depression areas within the drainage basin is more dominant than the hilly areas. A question at this junction, what is meant by hilly (depression) areas? Do we need to consider the heights or the areal extensiveness of these areas? The more extensive the hilly (depression) area the bigger (smaller) is be the $n$ value away from the flat area case of $n=1$.

\section{Peak discharge-rainfall intensity relationship}

Now, let us ask the same question as for the relationship between the rainfall intensity, I, and the peak discharge, Qp. Logically, the intensity is directly proportional to Qp, but what about its type as for the linearity? Furthermore, if antecedent conditions, such as soil moisture, surface cover features (manmade or natural, i.e., geological) and evapotranspiration are considered, then logical and rational thinking leads to a nonlinear relationship between the discharge ratio, $\mathrm{q}=\mathrm{Q} / \mathrm{Qp}$ and rainfall intensity ratio, $\mathrm{i}=\mathrm{I} /$ Imax as in Figure 2.3.

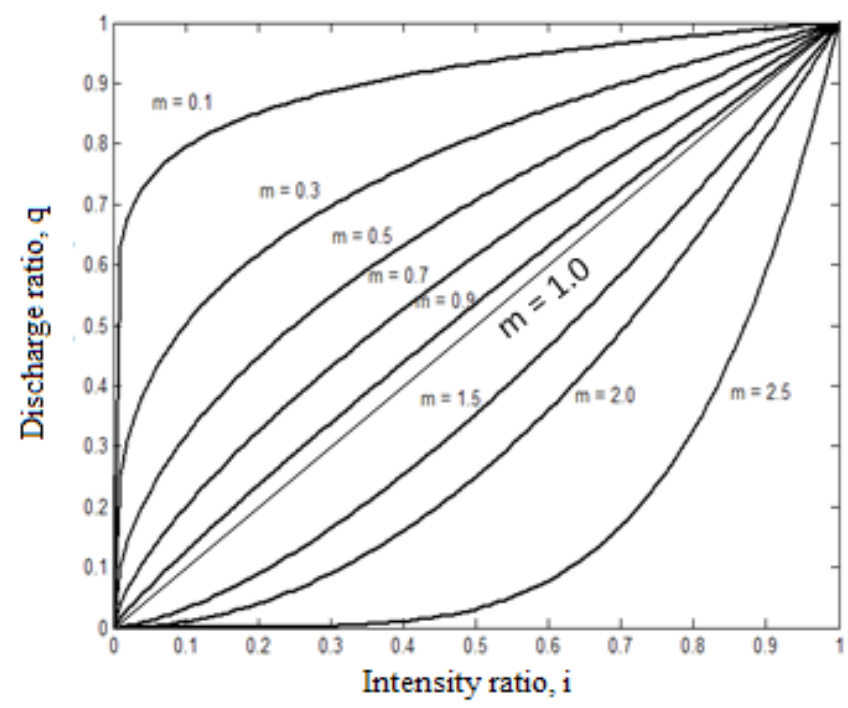

Figure 2.3. Peak discharge excess rainfall ratio relationship 
Herein, $\mathrm{m}$ indicates the non-linearity power that depends on the mutual interaction between the rainfall and the drainage basin surface features in addition to the meteorologically prevailing conditions. Logically, low m values correspond to business, residential and asphaltic areas where surface permeability is rather high. High $\mathrm{m}$ values imply delay in the surface flow occurrence at small rainfall intensities and after the saturation is reached the runoff takes place at high rates which corresponds to curves below $\mathrm{m}=1.0$ line in Figure 2.3.

Additional interpretations from Figure 2.3 lead to the following significant points as for the surface flow within a drainage basin.

1) The more (less) permeable the drainage basin surface the bigger (smaller) is the runoff exponent value than $m=1$, which corresponds to completely impervious drainage area,

2) For m values more (less) than 1 the surface peak discharge starts rather slowly (rapidly) and then the rate of discharge decreases (increase) with the rainfall intensity.

\section{Peak discharge-drainage slope relationship}

Another significance missing factor in the classical RM is the catchment slope. In its present form the RM provides the runoff over a horizontal and flat surface areas, but how could flow take place without slope? Logically, the more the slope the less is the discharge, and therefore, inverse but a non-linear relationship is expected between peak discharge Qp and slope, S.as in Figure 2.4.

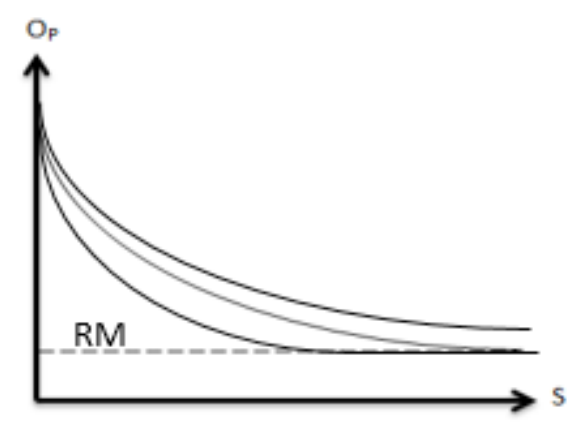

Figure 2.4. Peak discharge slope relationship

This figure indicates that there is an exponential relationship between QP and S, which appears in the mathematical form as,

QP $\quad \alpha_{\mathrm{S}} \mathrm{e}^{-\mathrm{kS}}$

One can write mathematical equation by introducing a proportionality parameter, $\mathrm{Cp}$, leading to,

$\begin{array}{llll}Q_{p} & \alpha_{G} & A^{n} I^{m} e^{-k s}\end{array}$ 
This expression leads to the physical definition of the proportionality parameter as the runoff discharge that corresponds to per drainage basin area $(\mathrm{km} 2)$, per rainfall intensity $(\mathrm{mm})$ on a flat surface $(\mathrm{S}=1)$.

On the other hand, the same expression can be reduced to the classical rational formula by considering that $\mathrm{n}=\mathrm{m}=1$ and $\mathrm{S}=0$. In this special case, $\mathrm{Cp}$ has then the equivalent value to the runoff coefficient. In the RM physically, $\mathrm{C}$ is the ratio of runoff volume to excess rainfall volume over the drainage area, which is dependent on the permeability of the surface material, and accordingly, necessary tables help to identify its numerical value (Maidment, 1993). However, in Eq. (7) Cc has a different definition as reflecting not only the soil permeability but additionally the effects of the non-linearity as explained before.

\section{Results}

The application of the methodology presented in this paper is applied to Wadi Baish in the Kingdom of Saudi Arabia. It is one of the largest drainage basins in southwestern Saudi Arabia (Figure 3.1) with approximately 5,970 km2 area. Different physiographic variables, in addition to rock, soil and vegetation variables are measured in Wadi Baish drainage area. Several physiographic parameters are measured, reviewed, analyzed and used in appropriate equations to synthesize a unit hydrograph for the Wadi Baish catchment area. Full detail information is available in the report by the Saudi Geological Survey (Al-Zahrani, et al., 2007).

The whole Baish catchment has 54 sub-basins as shown in Figure 3.1, and detailed application of the Soil Conservation Service (SCS) methodology to each sub-basin has provided the basic data including area, slope and discharge values (see Table 3.1).

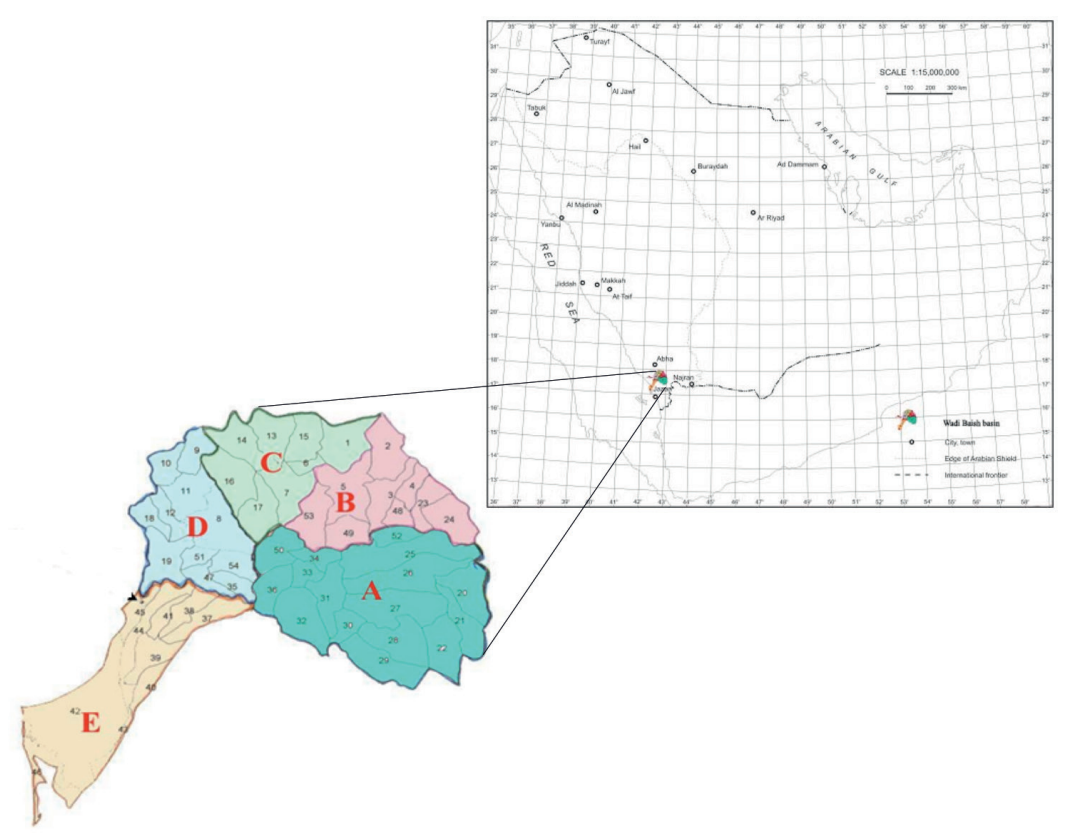

Figure 3.1. Location map of the study area and Wadi Baish sub-basins 
Table 3.1.

Geomorphological features of Wadi Baish sub-basins

\begin{tabular}{llllllll}
\hline $\begin{array}{l}\text { Sub-basin } \\
\text { No. }\end{array}$ & Area $\left(\mathrm{km}^{2}\right)$ & So & $\begin{array}{l}\text { Discharge } \\
\left(\mathrm{m}^{3} / \mathrm{sec}\right)\end{array}$ & $\begin{array}{l}\text { Sub-basin } \\
\text { No. }\end{array}$ & Area $\left(\mathrm{km}^{2}\right)$ & So & $\begin{array}{l}\text { Discharge } \\
\left(\mathrm{m}^{3} / \mathrm{sec}\right)\end{array}$ \\
\hline 1 & 146.5 & 0.048 & 466.066 & 28 & 153 & 0.058 & 610.9423 \\
2 & 134 & 0.058 & 511.7341 & 29 & 146.8 & 0.045 & 605.7025 \\
3 & 100.9 & 0.064 & 590.4745 & 30 & 51.21 & 0.068 & 270.3481 \\
4 & 51.61 & 0.098 & 334.2873 & 31 & 112.5 & 0.051 & 481.911 \\
5 & 176.3 & 0.052 & 668.0169 & 32 & 168.9 & 0.079 & 565.8286 \\
6 & 27.06 & 0.079 & 236.0097 & 33 & 44.77 & 0.039 & 290.6617 \\
7 & 135.3 & 0.059 & 540.8138 & 34 & 49.21 & 0.031 & 363.7294 \\
8 & 181.4 & 0.067 & 570.6024 & 35 & 52.45 & 0.074 & 357.2733 \\
9 & 78.22 & 0.115 & 359.756 & 36 & 90.7 & 0.085 & 447.4473 \\
10 & 69.96 & 0.047 & 339.687 & 37 & 108.3 & 0.051 & 657.7244 \\
11 & 118.7 & 0.041 & 512.5776 & 38 & 74.42 & 0.032 & 526.4656 \\
12 & 58.15 & 0.044 & 414.2175 & 39 & 93.51 & 0.007 & 485.4893 \\
13 & 113.8 & 0.079 & 500.6066 & 40 & 53.7 & 0.041 & 387.1429 \\
14 & 126.3 & 0.071 & 606.3679 & 41 & 41.48 & 0.018 & 339.3307 \\
15 & 104.9 & 0.074 & 479.2184 & 42 & 535.9 & 0.002 & 1239.822 \\
16 & 146.1 & 0.065 & 595.2061 & 43 & 49.01 & 0.021 & 484.3066 \\
17 & 123.2 & 0.046 & 449.2771 & 44 & 112.4 & 0.023 & 552.1155 \\
18 & 57.41 & 0.039 & 390.3996 & 45 & 60.27 & 0.016 & 414.1791 \\
19 & 144.5 & 0.033 & 520.5371 & 47 & 53.73 & 0.029 & 372.6239 \\
20 & 128.2 & 0.042 & 548.0393 & 48 & 43.15 & 0.095 & 240.9954 \\
21 & 99.57 & 0.026 & 637.634 & 49 & 89.15 & 0.076 & 380.698 \\
22 & 132.1 & 0.044 & 526.0269 & 50 & 107.7 & 0.055 & 434.3845 \\
23 & 71.45 & 0.04 & 358.0542 & 51 & 38.3 & 0.08 & 269.1822 \\
24 & 125.3 & 0.055 & 495.3614 & 52 & 71.45 & 0.056 & 371.5351 \\
25 & 219.6 & 0.037 & 903.6417 & 53 & 124 & 0.087 & 429.8804 \\
26 & 194.7 & 0.026 & 880.6327 & 54 & 73.32 & 0.078 & 375.4878 \\
27 & 207.6 & 0.025 & 799.1697 & & & & \\
\hline
\end{tabular}

The scatter of peak discharge versus area is presented in Figure 3.2a for ordinary and in Figure $3.2 \mathrm{~b}$ for double logarithmic scales. One can observe that on the double logarithmic plot the scatter of points lie along a straight-line with slope equal to $\mathrm{n}=0.55$. 
On the other hand, since the straight-line passes through $\mathrm{Qp}=500$ and $\mathrm{A}=100 \mathrm{~km} 2$ point, the equation form of Eq. (7) yields the constant as 40. Hence the valid peak discharge-area relationship appears as,

$\mathrm{Q}_{\mathrm{p}}=40 \mathrm{~A}^{0.55}$
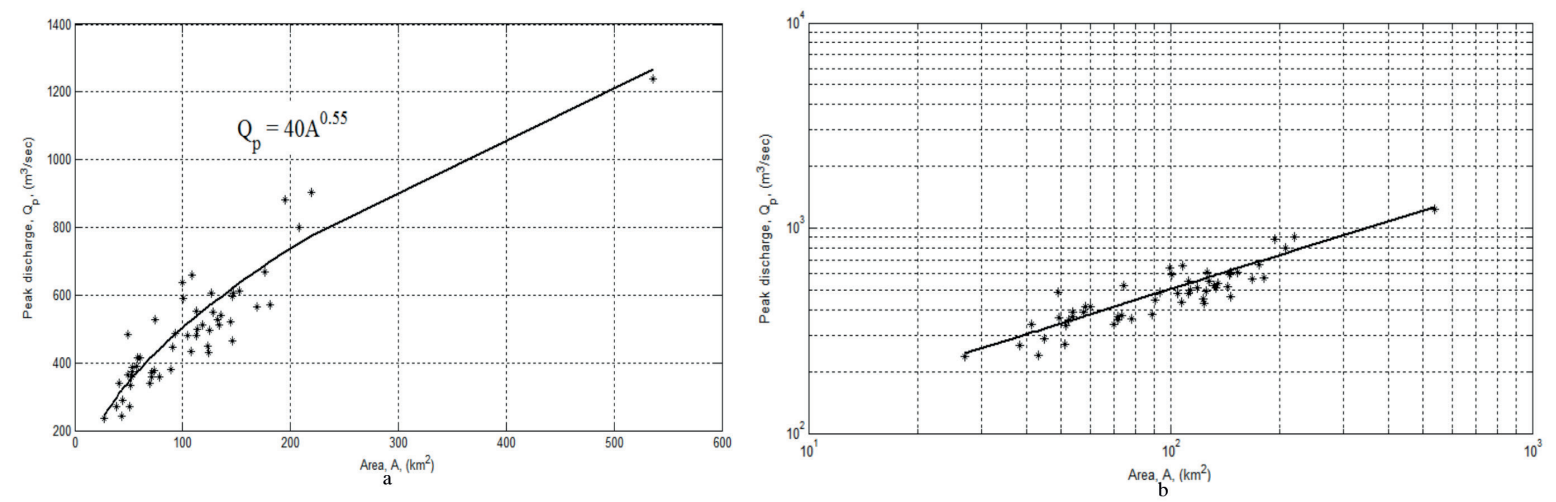

Figure 3.2. Peak discharge - area relationship

The slope relationship with the peak discharge is shown in Figure 3.3, where on the double logarithmic paper the relationship slope is equal to $\mathrm{k}=7.63$. Since the straight-line goes through the points with coordinates $(\mathrm{Qp}=700 \mathrm{~m} 3 / \mathrm{sec}, \mathrm{S}=0.00)$ and $(\mathrm{QP}=275, \mathrm{~S}=0.12)$, then the proportionality in Eq. (7) in the form of equation leads to a constant value approximately as 700 . Hence, the final expression between the peak discharge and drainage slope becomes as,

$$
\mathrm{Q}_{\mathrm{p}}=700 \mathrm{e}^{-7.63 \mathrm{SS}}
$$
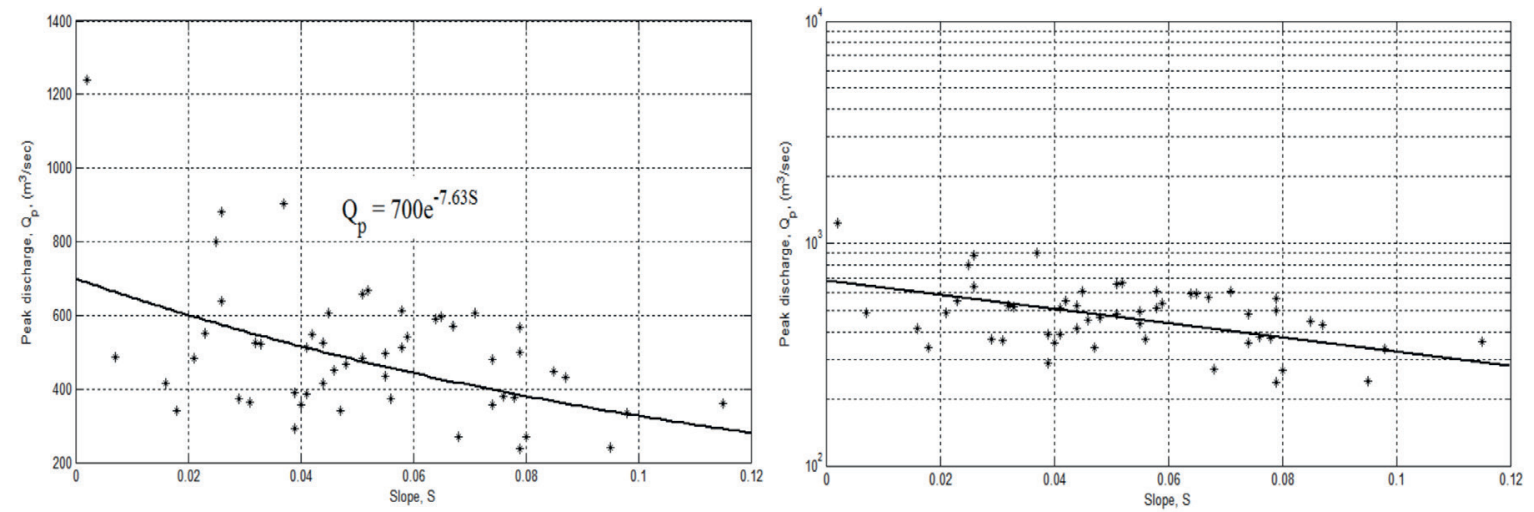

Figure 3.3. Peak discharge - slope relationship 
On the other hand, determination of the composite runoff coefficient, Cp, in Eq. (7) is possible by knowing the relationship for any region between the drainage area and the peak discharge, which is given for the study area by Şen and Al-Suba'i (2002) as,

$$
Q_{P}=43 A^{0.52}
$$

After all the calculation and determination of the constants, the final formulation for Wadi Baish becomes as follows.

$$
Q_{P}=55 A^{0.55} I^{m} e^{-7.63 S}
$$

On the basis of maximum excess rainfall event this expression can be thought of two complementary but separate product components. The first version is for zero slope that indicates the area effect only and the other is unit area case that shows the slope effect. Both of these effects are given separately in Figure 3.4 with 45 o straight-line (1:1 line) that shows the model validity. It is obvious that the area effect is more than the slope, but the areal effect by itself cannot make acceptable predictions because all the points (upper triangles in the figure) lie over the straight-line, which implies that such an approach causes overestimation of the discharges. The slope has comparatively very small effect.

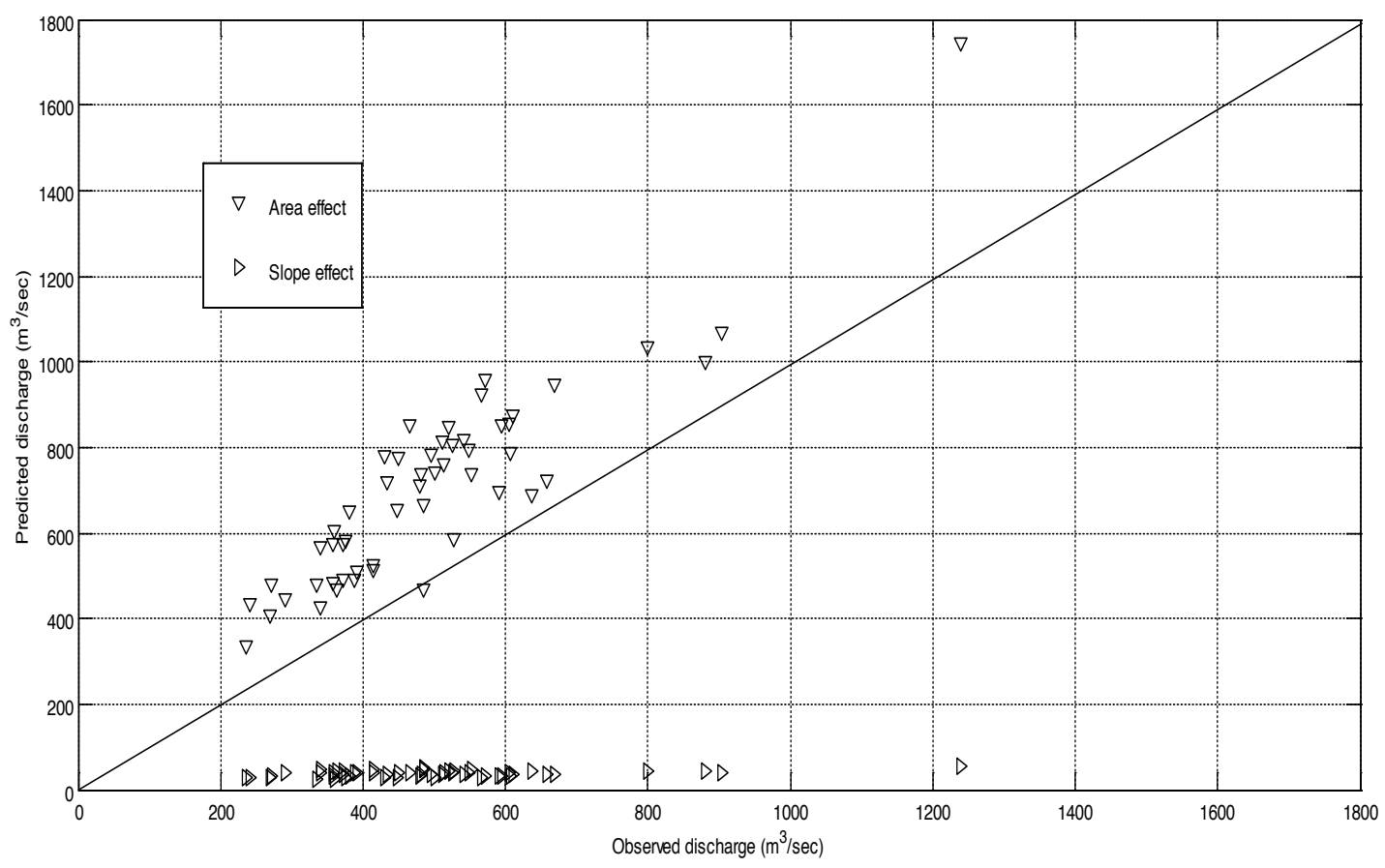

Figure 3.4. Area and slope effect on the discharge prediction 
In Figure 3.5, area and slope effects are considered together again for the case of maximum effective rainfall and the scatter of points are now around the $45 \mathrm{o}$ straight-line. In the same figure the $\mathrm{RM}$ result is shown for $\mathrm{C}=0.8$ and unit excessive rainfall amount. It is obvious that the $\mathrm{RM}$ is far away from the real data and it needs some rectification as presented in this paper.

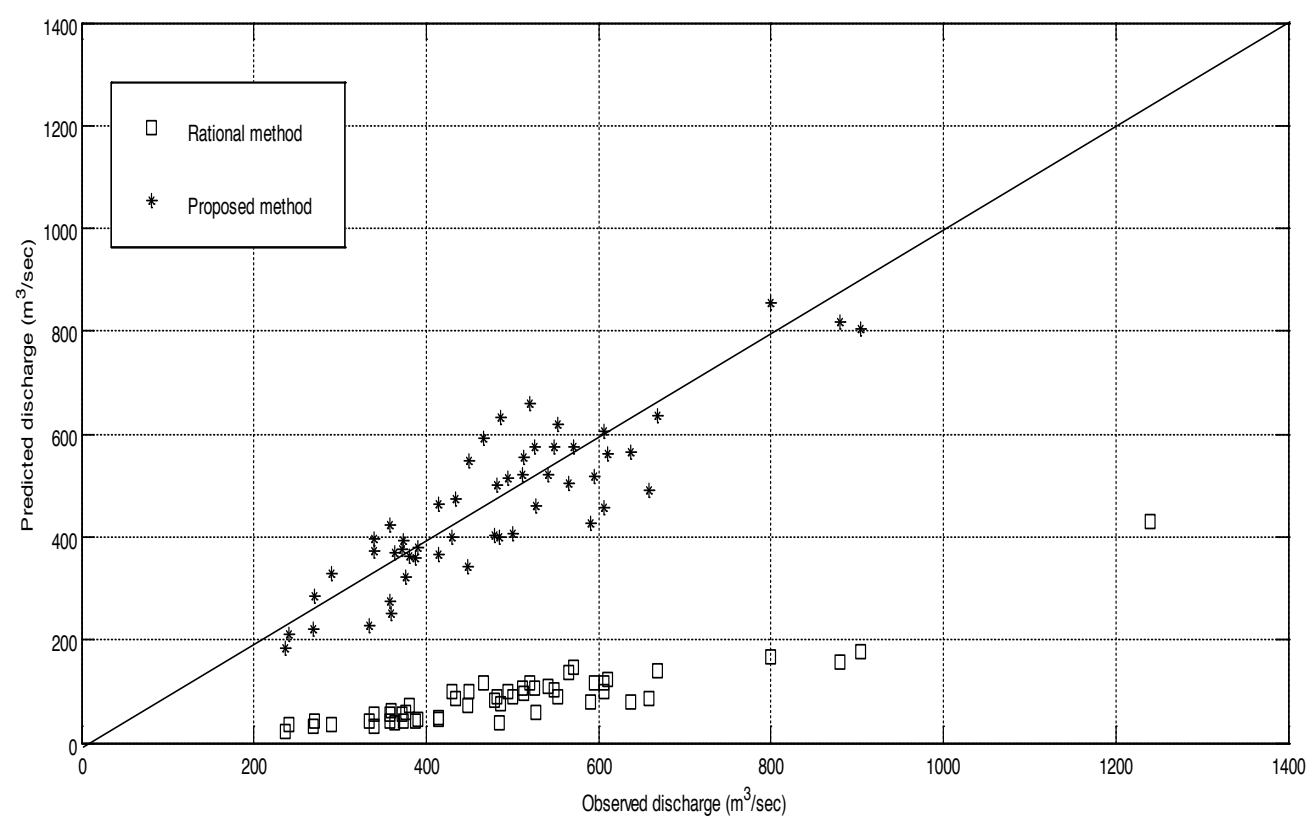

Figure 3.5. Combined effect of area and slope

After the application of the proposed method to given data, prediction errors' histogram and fitted Gaussian probability distribution function (pdf) are presented in Figure 3.6. It is obvious that the error distribution accords with the Gaussian (normal) pdf, which indicates the validity of the proposed model without any bias. The scatter of errors (deviations, residuals) of the proposed methodology scatter diagram from 45o line has almost Gaussian frequency distribution function as in Figure 3.6.

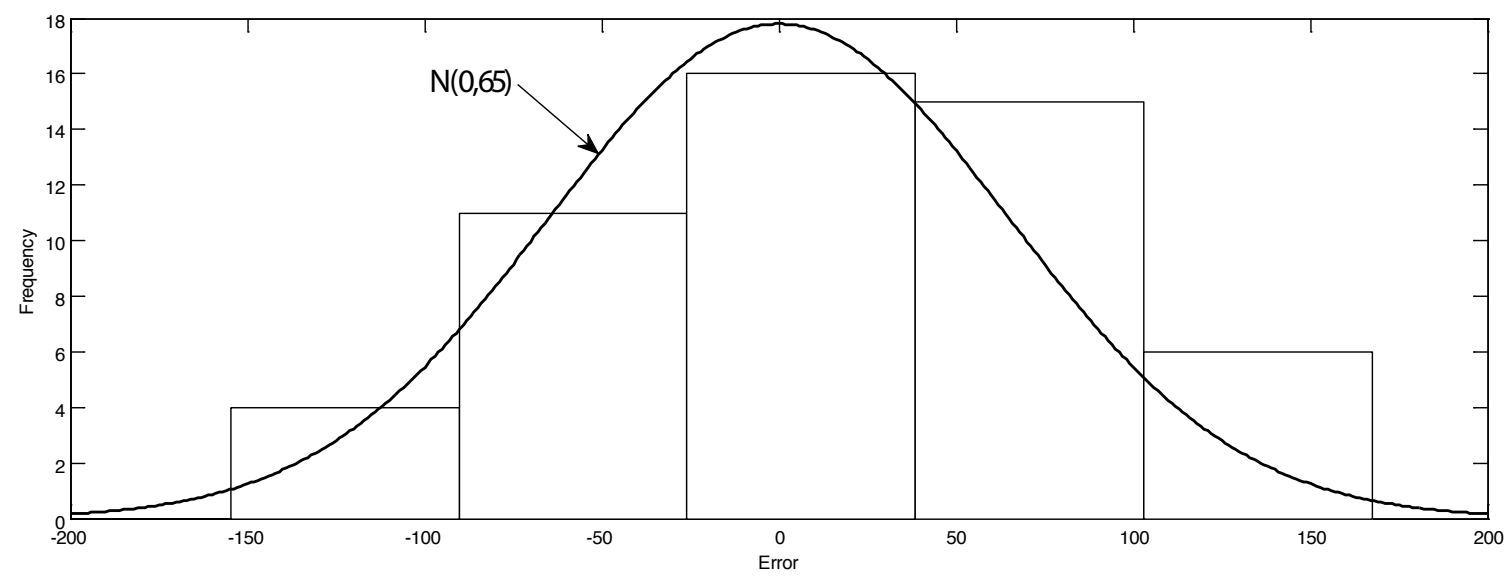

Figure 3.6. Error frequency distribution 


\section{Discussion and Conclusion}

Rational method (RM) formulation is considered as panacea for many practical applications in engineering hydrology such that the very word "rational" in its title leads many researchers not to criticize its structure except that it is restricted for use in small drainage basins only. Logical reasoning of the input variables such as the drainage area and rainfall intensity effect on the discharge impels one to suspect from the directly linear relationship between these parameters in addition to the missing drainage area slope in the formulation. It is well known from many synthetic and empirical studies that the peak discharge is not linearly related to the drainage area, the rainfall intensity and the slope. There is directly non-linear relationship between the peak discharge and the drainage area whereas the relationship between the slope and the peak discharge is inversely non-linear. Additionally, the peak discharge is directly proportional and non-linearly related to rainfall intensity. This paper presents all these logical non-linear relationships for the rectification of the rational formulation, which leads to another and more general peak discharge formulation. The application of this new procedure is checked against the peak discharges from Wadi Baish that lies in the southwestern province of the Kingdom of Saudi Arabia.

\section{References}

Al-Zahrani, M. K., Al-Harthi, S. G., Hawsawi, H. M., Al -Ammawi, F. A., Theban, M. S., Khiyami, H. A., Bulkhi, A., Şen, Z. (2007). Potential Flood Hazard in Wadi Baish Southwest, Saudi Arabia. Saudi Geological Survey Confidential Report, 216 pp.

Bayazıt, M., Önöz, B. (2008). Taşknn ve kurakllk hidrolojisi, Nobel Yayınevi, ISBN: 978-605-395-142-1, İstanbul, Ekim.

Chow, V., Maidment, D., Mays, L. (1988). Applied hydrology: McGraw-Hill, New York, 572 P.

Costa, J.E. (1987). A comparison of the largest rainfall-runoff floods in the United States with those of the People's Republic of China and the world in W.H. Kirby, S.Q. Hua and L.R. Beard, eds, Analysis of extraordinary flood events: Journal of Hydrology, v. 96, p. 101-115.

Hjelmfelt, Jr. A. T. (1991). Investigation of curve number procedure. Journal of Hydrologic Engineering, ASCE 117(6): 725-737.

Kirpich, Z. P. (1940). Time of concentration of small agricultural watersheds. Civil Engineering 10 (6), 362. The original source for the Kirpich equation.

Kadioglu M, Şen Z. (2001). Monthly precipitation-runoff polygons and mean runoff coefficients. Hydrological Sciences Journal 46(1): 3-11. 
Linsley, R.K. (1982). Rainfall - runoff models - an overview. In Proceedings of the International Symposium on Rainfall-Runoff Relationship, Singh VP(ed.). Water Resources Publications: Littleton, CO.

Maidment, D.R. (1993). Handbook of Hydrology. McGraw-Hill, Inc., New York.

Omolayo, A. S. (1993). On the transformation of areal reduction factors for rainfall frequency esti mations. Journal of Hydrology, 145, 191-205.

Pilgrim, D. H., Cordery, I. (1993). Flood Runoff. Handbook of Hydrology, Maidment DR (ed.). McGraw-Hill: New York; 9.1-9.42.

Ponce, V. M., Hawkins, R. H. (1996). Runoff curve number: has it reached maturity? Journal of Hydrologic Engineering, ASCE 1(1): 11-19.

Sirdaş, S., Şen, Z. (2007). Determination of Flash Floods in Western Arabian Peninsula Journal of Hydrologic Engineering, ASCE, Vol. 12 , No. 6, 676-681.

Şen, Z., Al-Suba'i K. (2002). Hydrological considerations for dam siting in arid regions: Saudi Arabia study. Hydrological Sciences Journal, 47(2) 173-186.

Şen, Z. (2008). Wadi Hydrology. Taylor and Francis Group, CRC Press, Boca Raton, 345 pp.

Şen, Z., (2010). Fuzzy Logic and Hydrological Modeling. Taylor and Francis Group, CRC Press Publishers, 340.

Soil Conservation Service (SCS). (1971). National Engineering Handbook, Section 4: Hydrology. USDA: Springfield, VA

Soil Conservation Service (SCS). (1986). Urban Hydrology for Small Watersheds, Technical Report 55. USDA: Springfield, VA. 


\section{Extended Turkish Abstract (Genişletilmiş Türkçe Özet)}

\section{Rasyonel Yöntemin Rasyonel Olmayışı ve İyileştirilmesi}

Yağış-akış ilişkisi, herhangi bir su kaynağının planlaması, tasarımı, işletmesi ve bakım çalışmasında önemli rol oynamaktadır. Bu ilişkinin tespiti küçük drenaj havzaları üzerine yapılan taşkın tahminleri, barajlar, kuşatmalar, menfezler ve toprak koruma amaçlı yapılar gibi mühendislik yapıları için gereklidir.

Özellikle, iklim değişikliği etkileri benzeri görülmemiş bir şekilde dünyanın farklı yerlerinde taşkınları tetiklemektedir ve dolayısıyla mühendisler tarafindan pratik olarak kullanılabilen basit modellerle daha iyi tahminler için daha rafine edilmiş formülasyonlar gereklidir. Küçük akarsularda taşkın tahminlerinde en sık kullanılan yöntemler rasyonel yöntem (RY) ve Toprak Koruma Hizmeti (SCS) yöntemi (SCS, 1971, 1986) 'dir. Bu yöntemler, tasarım yağış miktarı bilgilerinin verilmesi koşuluyla tasarım taşkın tahmini için kullanılır (Şen, 2008).

Birçok uygulamada C değeri sabit olarak kabul edilir, fakat doğada zamanla değişir ve özellikle debi ortalama yineleme aralığı hesaplanırken -önemli bir rol oynar. C değerinin tahmin edilmesi zordur ve birçok su kaynakları projesinde ana belirsizlik kaynağıdır. Oldukça belirsiz bir şekilde seçilirler ve büyük oranda gerçek saha verileri yerine öznel yargılar içerirler. Genel olarak, C, yağışın ortalama yinelenme aralığı arttıkça artmakta ve böylece drenaj havzasının akış geçiş tepkimesinde doğrusal olmayan bir ilişkiye neden olmaktadır..

RY, temel varsayımları mantıksal temelli olarak basitleştirmekle birlikte gerçek akış durumları için fiziksel olarak makul görülmemektedir. Varsayımları arasında pik akış hızı, tüm drenaj havzası alanı boyunca konsantrasyon periyoduna eşit bir süre muhafaza edilen sabit bir yağış yoğunluğu tarafindan üretilir. Bu zaman, teorik olarak, drenaj havzasının en uzak kısmından gelen yüzey akışının ilgili noktasına ulaşması için gereken süre olarak tanımlanmaktadır. Sahada ölçülebilmesi mümkün değildir ve bu nedenle ampirik olarak hesaplanmıştır (Kirpich, 1944; Şen, 2010). Buna ek olarak, mühendislerin sonuçların başarılı uygulamaları ve yorumları için bilmeleri gereken bir dizi varsayım vardır.

RY formülasyonunun rektifikasyonu aşağıdaki belirtilen esaslar göz önüne alarak mümkündür.

Pik debi olan Qp, doğrudan ve doğrusal olarak su toplama alanı ile doğru orantılı bir ifadeyi matematiksel olarak aşağıdaki gibi ifade etmek mümkündür:

$Q_{\mathrm{p}} \alpha_{\mathrm{A}} \mathrm{A}^{\mathrm{n}}$

Burada, $\alpha$ A orantıllılı işaretidir ve n, 1'den düşük bir değerdir ve bu, farklı toplama alanları ve pik debileri dahil olmak üzere mevcut veri setinden ampirik olarak saptanabilir.

Havza alanı ile pik debisi arasındaki ilişki direkt olarak RY'deki gibi alanla ilgilidir, ancak yüzey pürüzlülüğü bu iki nicelik arasında lineer olmayan bir ilişki doğurmaktadır.

$Q_{P}=500 A^{0.4}$ 
Bayazıt ve Önöz (2008), drenaj alanları ile pik yükü arasındaki ilişkiyi bulmak için yaptıkları çalışmalara dayanarak aşağıdaki koşullu ifadeleri öngörmüştür.

$$
\begin{array}{lc}
\mathrm{QP}=1.81 \mathrm{~A} 1.22 & \mathrm{~A} \leq 300 \\
\mathrm{QP}=79 \mathrm{~A} 0.5 & 300 \leq \mathrm{A} \leq 10000
\end{array}
$$

Ayrıca toprak nemi, yüzey kaplaması özellikleri ve evapotranspirasyonu gibi öncül koşullar göz önüne alındığında, mantıksal ve rasyonel düşünme, boşalma oranı ( $q=Q$ / Qp) arasında doğrusal olmayan bir ilişkiye neden olur ve yağış yoğunluğu oranı, i = I / Imax olarak kabul edilir.

$$
Q_{\mathrm{P}} \quad \alpha_{\mathrm{i}} \mathrm{I}^{\mathrm{m}}
$$

Burada, m, yağış ile drenaj havzası yüzey özellikleri arasındaki karşılıklı etkileşime bağlı olarak, meteorolojik olarak geçerli koşullara ek olarak doğrusal olmayan ilişkiyi belirtir.

Drenaj havzası yüzeyinin geçirgenliği ne kadar büyükse $m=1$ 'den daha büyük geçirgenlik değerini işaret eder ve bu da tamamen geçirimsiz drenaj alanına karşlık gelir, 1'den daha fazla olan $\mathrm{m}$ değerleri için, yüzey pik debisi oldukça yavaş başlar ve daha sonra yağış şiddeti ile debi oranı düşer.

Mantıksal olarak, eğim ne kadar fazla ise debi olur ve dolayısıyla ters, fakat pik debisi Qp ve eğim, S arasında doğrusal olmayan bir ilişki beklenir.

$$
\text { QP } \alpha_{S} e^{-k S}
$$

Burada, $\alpha \mathrm{S}$ başka bir orantı katsayısıdır ve k> 0'dır. Denk. (6), sıfır eğimin, klasik RY'ye uygun olan sabit debiye karşıllk geldiğini ima eder.

Yukarıdaki iki değişkenli orantılıkların hepsi çarpım işlemleri ile kombine edilebilir ve son formülasyon küresel bir orantısal katsayısı $\alpha \mathrm{G}$ ile aşağıdaki gibi yazılabilir:

$$
Q_{\mathrm{P}} \quad \alpha_{\mathrm{G}} \quad \mathrm{A}^{\mathrm{n}} \mathrm{I}^{\mathrm{m}} \mathrm{e}^{-\mathrm{kS}}
$$

Bir orantı parametresi olan Cp'yi getirerek matematik denklemi yazabilir,

$$
Q_{P}=C_{p} A^{n} I^{m} e^{-k S}
$$

$\mathrm{Bu}$ ifade, düz yüzeyde $(\mathrm{S}=1)$ yağış yoğunluğu $(\mathrm{mm})$ başına drenaj havza alanı $(\mathrm{km} 2)$ için karşılık gelen akış debisi olarak orantı parametresinin fiziksel tanımlanmasına yol açar.

Metodoloji Suudi Arabistan Krallığı'ndaki 54 alt havzaya ayrılmış, 5,970 km2'lik alana sahip olan Wadi Baish'e uygulanmıştır. Wadi Baish drenaj alanında kaya, toprak ve vejetasyon değişkenlerine ek olarak farklı fizyolojik değişkenler ölçülmektedir. Wadi Baish havzası için bir birim hidrografı sentezlemek için çeşitli fizyografik parametreler ölçülmekte, gözden geçirilmekte, analiz edilmekte ve uygun denklemlerde kullanılmaktadır. 
Biri çift logaritmik grafiğin noktalarının dağılımı eğrisi $\mathrm{n}=0.55^{\prime} \mathrm{e}$ eşit olan düz bir çizgi boyunca uzanmaktadır. Öte yandan, düz çizgi $Q p=500$ ve $A=100 \mathrm{~km} 2$ noktasından geçtiği için Denk. (7) sabiti 40 olarak verir. Dolayısıyla geçerli pik debi alanı ilişkisi şöyle gerçekleşir:

$$
Q_{P}=C_{p} A^{n} I^{m} e^{-k S}
$$

Çift logaritmik kağıt üzerinde ilişki eğimi $\mathrm{k}=7.63$ 'e eşittir. Denk. (7) şeklinde yaklaşık 700 olarak sabit bir değer bulunur. Dolayısıyla, pik debi ve drenaj eğimi arasındaki son ifade şu şekli alır:

$$
Q_{\mathrm{P}}=700 \mathrm{e}^{-7.63 \mathrm{SS}}
$$

Öte yandan, Eşit akış katsayısının (Cp) (7), çalışma alanı için Şen ve Al-Suba'i (2002) tarafından verilen drenaj alanı ile pik debi arasındaki herhangi bir bölgenin ilişkisini bilmek suretiyle mümkündür,

$$
Q_{P}=43 A^{0.52}
$$

Sabitlerin hesaplanması ve belirlenmesinden sonra, Wadi Baish'in son formülasyonu aşağıdaki gibi olur:

$$
Q_{P}=55 A^{0.55} \mathrm{I}^{\mathrm{m}} \mathrm{e}^{-7.63 \mathrm{~S}}
$$

Maksimum aşırı yağış olayına dayanarak, bu ifade iki tamamlayıcı fakat ayrı ürün bileşeni olarak düşünülebilir. Alan efektinin eğimden daha fazla olduğu açıktır, ancak tüm alanlar düz çizginin üzerinde kaldığı için bölgedeki alansal etki kendiliğinden kabul edilebilir tahminlerde bulunamaz; bu da böyle bir yaklaşımın aşırı tahmin edilmesine neden olduğu anlamına gelir. Eğim nispeten çok küçük bir etkiye sahiptir.

Maksimum etkili yağış durumunda bölge ve eğim efektleri bir arada düşünülür ve noktaların saçılması 450 düz çizginin etrafındadır. Açıktır ki RY, gerçek verilerden uzaktır ve bu makalede sunulan bazı düzeltmelere ihtiyaç duyar.

Rasyonel yöntem (RY) formülasyonu, mühendislik hidrolojisinde pek çok pratik uygulama için her derde deva olarak kabul edilir; bu nedenle, adında "rasyonel" kelimesi, birçok araştırmacıya, yalnızca küçük drenaj havzalarında kullanım için sınırlandırıldığı için yapısını eleştirmemesine neden olur. Birçok sentetik ve ampirik çalışmadan pik debinin drenaj alanı, yağış yoğunluğu ve eğim ile lineer olarak ilişkili olmadığı çok iyi bilinmektedir. Pik debi ile drenaj alanı arasında doğrusal olmayan bir ilişki bulunurken, eğim ile pik debi arasındaki iliş̧i tersine doğrusal değildir. Buna ek olarak, pik debi doğrudan doğruya orantılıdır ve yağış şiddetiyle doğrusal olmayan şekilde ilişkilidir. $\mathrm{Bu}$ makale rasyonel formülasyonun düzeltilmesi için tüm bu mantıksal lineer olmayan ilişkileri sunmaktadır ve bu da başka ve daha genel bir pik debi formülasyonuna yol açmaktadır. 